\title{
TALAK DI LUAR PENGADILAN PERSPEKTIF FIKIH DAN HUKUM POSITIF
}

\author{
M. Muhsin \\ Fakultas Syariah IAIN Ponorogo
}

\author{
Soleh Hasan Wahid
}

Fakultas Syariah IAIN Ponorogo

solehhasan80@gmail.com

\begin{abstract}
Divorce is breaking the ties of marriage and ending the relationship between husband and wife. According to Figh law, divorce is considered legally binding when a husband pronounces the word talak to his wife both clearly and figuratively. Meanwhile, according to Law Number 1 of 1974 concerning Marriage, it is explained that divorce can only be carried out before the court after the court concerned tries and fails to reconcile the two parties. The focus of the problem in this study are: (1) What is the status of divorce outside the court according to figh law and positive law? (2) Which is used as a guideline between the two divorce proceedings on the termination of marriage? The type of research conducted by the author is a field research using qualitative methods. The analysis used is descriptive analysis method. The number of respondents in this study were five people with the category of divorce outside the court. Based on the method used in the study, it was concluded that the divorce handed down out of court was legal according to figh, so that the marriage broke up in accordance with figh rules. However, the divorce is not legal according to positive law in Indonesia, so that in the eyes of positive law the marriage has not been broken and the positive law that applies in Indonesia is used as a guide to the termination of marriage, because the legal consequences that arise after the divorce are more clearly regulated, so that obligations and rights that arise after the divorce is more secure.
\end{abstract}

KEYWORD: Divorce, fiqh, and positive law

ABSTRAK: Talak adalah melepaskan ikatan pernikahan dan mengakhiri hubungan suami istri. Menurut hukum Fikih perceraian dianggap jatuh hukumnya ketika seorang suami mengucapkan kata talak kepada istrinya baik secara jelas maupun kiasan. Sedangkan menurut UndangUndang Nomor 1 Tahun 1974 Tentang Perkawinan dijelaskan bahwa perceraian hanya dapat dilakukan di depan pengadilan setelah pengadilan yang bersangkutan berusaha dan tidak berhasil mendamaikan kedua belah pihak. Fokus masalah dalam penelitian ini adalah: (1) Bagaimana status talak di luar pengadilan menurut hukum fikih dan hukum positif? (2) Manakah yang dijadikan pedoman antara dua proses perceraian terhadap putusnya perkawinan? Jenis penelitian yang dilakukan penulis merupakan penelitian lapangan (field research) yang menggunakan metode kualitatif. Analisis yang digunakan adalah metode analisis deskriptif. Jumlah responden dalam penelitian ini sebanyak lima orang dengan kategori melakukan penceraian di luar Pengadilan. Berdasarkan metode yang digunakan dalam penelitian dihasilkan kesimpulan bahwa, talak yang dijatuhkan di luar pengadilan adalah sah menurut fikih, sehingga perkawinannya putus sesuai dengan aturan fikih. Namun perceraian tersebut tidak sah menurut hukum positif di Indonesia, sehingga di mata hukum positif perkawinannya belum putus dan hukum positif yang berlaku di Indonesia yang dijadikan sebagai pedoman terhadap putusnya perkawinan, dikarenakan akibat hukum yang ditimbulkan setelah terjadinya perceraian lebih diatur dengan jelas, sehingga kewajiban dan hak yang timbul setelah terjadinya perceraian lebih terjamin.

KEYWORDS: Talak, Fikih, dan Hukum Positif 


\section{INTRODUCTION}

Perkawinan ialah ikatan lahir batin antara seorang pria dengan seorang wanita sebagai suami istri dengan tujuan membentuk keluarga yang bahagia dan kekal berdasarkan Ketuhanan Yang Maha Esa. ${ }^{1}$ Keabadian atau kekekalan sebuah perkawinan merupakan tujuan utama yang diidam-idamkan oleh suami dan istri. Akad nikah dilaksanakan untuk selamanya untuk membangun rumah tangga sejak pertama akad dan seterusnya hingga meninggal dunia, agar suami istri bersama-sama dapat mewujudkan rumah tangga sebagai tempat berlindung, menikmati naungan kasih sayang dan dapat memelihara anak-anaknya dalam pertumbuhan yang baik. Oleh karena itu dikatakan bahwa "Ikatan antara suami istri adalah ikatan paling suci dan paling kokoh". Dan tidak ada dalil yang lebih jelas menunjukan tentang sifat kesucian dari sebuah akad perkawinan, sehingga Allah sendiri yang menamakan ikatan perjanjian antara suami istri dengan "Mithaqan ghaliza" (ikatan yang kuat). Oleh karena itu jika ikatan antara suami istri kokoh dan kuat, tidak sepatutnya dirusak dan disepelekan. Setiap usaha untuk menyepelekan hubungan perkawinan dan melemahkannya sangat dibenci Allah, karena ia merusak kebaikan dan menghilangkan kemaslahatan sebuah rumah tangga. ${ }^{2}$

Membina rumah tangga yang kekal bukan perkara yang mudah, suami istri sebelumnya harus memiliki bekal pengetahuan yang cukup tentang nilai, norma dan moral yang benar, harus siap dengan kemungkinan yang akan dihadapi berupa rintangan dan tantangan yang dapat mengakibatkan keretakan rumah tangga. Tak jarang juga rumah tangga yang telah dibangun sejak awal di tengah perjalanan mengalami perceraian yang disebabkan oleh berbagai hal.

Talak berasal dari kata "ițlaq", artinya melepaskan atau meninggalkan. Dalam istilah agama, talak artinya melepaskan ikatan perkawinan atau bubarnya hubungan perkawinan. Melepaskan ikatan pernikahan artinya membubarkan hubungan suami istri sehingga berakhirlah perkawinan atau terjadi perceraian. Perceraian dalam bahasa Indonesia dipakai dalam pengertian yang sama dengan talak, yang memiliki arti bubarnya pernikahan. Sebagaimana hukum perkawinan, hukum perceraian dalam Islam juga sering kali kerap menimbulkan salah paham, seakan-akan ajaran Islam memberikan hak yang lebih besar kepada laki-laki daripada perempuan. Padahal, betapa hati-hatinya hukum Islam dalam mengatur soal perceraian, dan tidak salah kalau dikatakan bahwa tiada satu agama atau peraturan manusia pun yang dapat menyamainya. Hak laki-laki dan perempuan begitu seimbang sehingga mencerminkan rasa keadilan yang luhur. ${ }^{3}$

Berdasarkan data yang ada di Pengadilan Agama Kabupaten Pacitan, pada bulan November 2018 terdapat 910 pengajuan perkara perceraian, 642 kasus merupakan cerai gugat, 268 kasus lainnya sebanyak 268 kasus. Perkara perceraian ini merupakan kasus yang terdaftar. Jika dirata-rata maka sejak Januari maka setiap bulannya lebih dari 82 pasangan bercerai. Jika dipersempit lagi, setiap harinya terjadi 2-3 perceraian. ${ }^{4}$

Selain kasus perceraian terdaftar di atas, masih banyak kasus perceraian lain yang tidak diajukan ke pengadilan. Seperti, hasil observasi awal yang dilakukan oleh peneliti,

\footnotetext{
${ }^{1}$ Indonesia., Undang-undang perkawinan: Undang-undang Republik Indonesia nomor 1 tahun 1974 tentang perkawinan : berikut penjelasannya (Jakarta: Alda/Pentja, 1974).

2 Beni Ahmad Saebani, FIQH MUNAKAHAT 2, ed 1 cet 5 (Bandung: Pustaka Setia, 2016).,61.

${ }^{3}$ Ahmad Saebani.,55.

${ }^{4}$ Rohmad (Nama Samaran), “Hasil Wawancara Dengan Hakim PA Dan Masyarakat Sekitar" (Pacitan, 2020).
} 
terdapat pasangan suami istri yang telah menikah pada tanggal 1 Februari 1993 sebagaimana tercatat dalam duplikat Kutipan Akta Nikah sehingga karenanya pernikahan tersebut sah secara hukum. Rumah tangga keduanya berjalan harmonis hingga Mei 2018, namun tak disangka pada awal bulan Juni 2018 mulai timbul pertengkaran yang disebabkan oleh masalah ekonomi. Puncak pertengkaran kedua pasangan suami istri tersebut terjadi sekitar bulan Maret 2019 dengan permasalahan yang sama. Selama terjadi pertengkaran, suami telah mengucapkan talak tiga kali. ${ }^{5}$

Atas dasar itulah, peneliti memilih subjek penelitian terkait perceraian di luar pengadilan adalah masyarakat di Kecamatan Pacitan, Kabupaten Pacitan. Di daerah ini, beberapa orang menikah secara sah di mata hukum, tetapi ketika mereka bercerai, suami istri tidak bercerai melalui sidang pengadilan, keduanya lebih suka bercerai di luar pengadilan. Artinya suami istri hanya bercerai secara agama tetapi tidak secara sah bercerai dari Negara. Hal ini tentunya menjadi perhatian pemerintah dan pemangku kepentingan dimana aturan hukum perkawinan diabaikan, yang seharusnya memberikan perlindungan dan jaminan bagi pihak yang diceraikan.

Selain kasus yang dipaparkan peneliti di atas, terdapat beberapa kasus sejenis dengan konteks yang berbeda di Kecamatan Pacitan, Kabupaten Pacitan, berdasarkan penelusuran peneliti diperoleh lebih dari 10 kasus perceraian. ${ }^{6}$ Dari 10 kasus ini dipilih 5 jenis kasus perceraian dengan pertimbangan hanya memilih responden yang berkenan menandatangani informed consent.

Sehubungan dengan kasus perceraian diluar pengadilan, menurut agama Islam perceraian dianggap jatuh hukumnya ketika seorang suami mengucapkan kata talak kepada istrinya baik secara jelas maupun kiasan. Sedangkan menurut hukum positif, suatu perceraian dianggap terjadi beserta akibat-akibatnya terhitung sejak jatuhnya putusan Pengadilan Agama yang telah mempunyai kekuatan hukum yang tetap. Dikarenakan suami yang tidak tahan dengan tuntutan istrinya yang terjadi secara terus menerus dan merasa pertengkaran antara keduanya tidak bisa dihindarkan serta rumah tangga keduanya yang tidak bisa dipertahankan lagi, pada akhirnya suami mengajukan gugatan ke Pengadilan Agama Pacitan. Setelah melalui proses persidangan yang menghasilkan putusan Pengadilan Agama Pacitan Nomor 1245/Pdt.G/2019/PA.Pct dijelaskan bahwa telah terjadi perceraian antara pemohon dan termohon. Yang mana dalam putusan tersebut berisikan memberikan izin terhadap suami untuk menjatuhkan talak satu raj' i. ${ }^{7}$

Kajian terkait talak diluar pengadilan bukan hal baru, Zainuddin, dkk., dalam kajiannya mengulas perihal kejadian isbat nikah sebagai bentuk implikasi dari talak yang telah dijatuhkan suami di luar pengadilan. Dalam salah satu temuannya dinyatakan bahwa terdapat cukup banyak problem dari kejadian talak semacam ini, yakni problem keabsahan, kemungkinan talak yang lebih dari sekali dan minimnya perlindungan hukum. ${ }^{8}$ Selanjutnya, Muhammad Isa permasalahan talak diluar pengadilan dengan menggunakan dua perspektif yakni perspektif Undang-Undang

5 Abdul (Nama Samaran), “Hasil Wawancara” (Pacitan, 2020).

${ }^{6}$ Rohmad (Nama Samaran), "Hasil Wawancara Dengan Hakim PA Dan Masyarakat Sekitar."

${ }^{7}$ Rohmad (Nama Samaran).

${ }^{8}$ Zainuddin Zainuddin, Khairina Khairina, and Sulastri Caniago, "ITSBAT TALAK DALAM PERSPEKTIF HUKUM PERKAWINAN DI INDONESIA,” Al-Ahwal: Jurnal Hukum Keluarga Islam 12, no. 1 (August 7, 2020): 29, https://doi.org/10.14421/ahwal.2019.12103. 
Perkawinan dan Perspektif Kompilasi Hukum Islam. ${ }^{9}$ Penelitian terbaru dengan topik ini dilakukan oleh Sofi'ul Majid, dkk, ia mengaji praktik perceraian di luar pengadilan dengan pendekatan studi kasus pada Desa Sirahan Kecamatan Cluwak Kabupaten Pati, norma hukum yang digunakan adalah Kompilasi Hukum Islam dan UU Perkawinan. Secara lebih spesifik kajian diarahkan pada ukuran mafsadat dan madharat dari talak diluar pengadilan. ${ }^{10}$

Setelah mengemukakan beberapa literatur terdahulu, ditemukan bahwa sampai saat ini kajian mengenai talak diluar pengadilan yang mencoba mengurai secara langsung beberapa kasus dengan pendekatan fenomologi belum dilakukan. Terlebih lagi jika dihubungkan dengan lokasi penelitian di wilayah Pacitan. Urgensi melakukan kajian ini menjadi lebih relevan.

Berdasarkan uraian di atas menimbulkan pertanyaan mengenai status talak yang diucapkan suami di luar Pengadilan serta manakah yang harus dipatuhi antara hukum fikih dengan putusan Pengadilan Agama.

Jenis penelitian yang dilakukan penulis merupakan penelitian lapangan (field research) yang menggunakan metode kualitatif. Sedangkan teknik pengumpulan data yang dilakukan adalah dengan metode wawancara dan observasi. Analisis yang digunakan adalah metode analisis deskriptif yaitu penelitian yang bertujuan utuk mengumpulkan data kemudian di analisis untuk mengambil kesimpulan.

\section{TALAK PERSPEKTIF FIQH DAN HUKUM POSITIF}

Menurut bahasa, al-tala $q$, berasal dari kata al-itlaq, yang berarti melepaskan atau meninggalkan. Misalnya, ketika anda mengatakan "Saya melepaskan tawanan" berarti anda telah membebaskannya. Menurut istilah, talak adalah melepaskan ikatan pernikahan dan mengakhiri hubungan suami isteri. ${ }^{11}$ Menurut Al-Jaziry talak adalah menghilangkan ikatan perkawinan atau mengurangi pelepasan ikatannya dengan menggunakan kata-kata tertentu. ${ }^{12}$

Menurut Abu Zakaria Al-Anshari, talak ialah melepas tali akad nikah dengan kata talak dan yang semacamnya. ${ }^{13}$ Menurut Al-Jaziri, talak ialah menghilangkan ikatan perkawinan atau mengurangi pelepasan ikatannya dengan menggunakan kata-kata tertentu. ${ }^{14}$ Menurut buku yang dikutip oleh Ibnu Mas'ud dan Zainal Abidin talak adalah perbuatan halal yang dimurkai Allah. Talak artinya melepaskan. Dan menurut istilah syarak ialah melepaskan ikatan pernikahan dengan kata-kata atau lafal yang menunjukkan talak atau perceraian. ${ }^{15}$

\footnotetext{
${ }^{9}$ Muhammad Isa, "PERCERAIAN DI LUAR PENGADILAN AGAMA MENURUT PERSPEKTIF UNDANG-UNDANG NOMOR 1 TAHUN 1974 DAN KOMPILASI HUKUM ISLAM (Suatu Penelitian Di Wilayah Hukum Mahkamah Syar'iyah Aceh Besar)," Jurnal Ilmu Hukum 2, no. 1 (2014).

${ }^{10}$ Sofi'ul Majid, Yasin Arief, and Nur'i Yakin, "PRAKTIK PERCERAIAN DI LUAR PENGADILAN AGAMA DALAM PERSPEKTIF KOMPILASI HUKUM ISLAM (Studi Kasus Desa Sirahan Kec. Cluwak Kab. Pati (2017)," in KONFERENSI ILMIAH MAHASISWA UNISSULA (KIMU) 2, 2019, 1256-62.

${ }_{11}$ As-Sayyid. Sabiq et al., Figh Sunnah (Kuala Lumpur: Al-Hidayah Publication, 2009).

${ }^{12}$ Rusli Halil Nasution, "TALAK MENURUT HUKUM ISLAM," Jurnal Ilmiah Al-Hadi 3, no. 2

(2018): 707-16, http://jurnal.pancabudi.ac.id/index.php/alhadi/article/view/357.

${ }^{13}$ Halil Nasution.

${ }^{14}$ Halil Nasution.

${ }^{15}$ Ibnu Mas'ud and Zainal Abidin, Fiqih madzhab Syafi'i (Bandung: Pustaka Setia, 2000).
} 
Talak secara harfiah berarti membebaskan ikatan seekor binatang. Istilah ini dipergunakan syariat untuk menunjukkan cara yang sah mengakhiri suatu perkawinan. kata-kata talak atau cerai itu harus selalu dijaga ketat, tidak diucapkan dengan tergesagesa, penuh emosi dan tidak menggunakan hak mencerai ini sewenang-wenang. ${ }^{16}$

Menurut buku yang dikutip oleh Anshori Umar talak artinya menceraikan atau melepaskan. Sedangkan menurut syarak, yang dimaksud talak ialah memutuskan tali perkawinan yang sah, baik seketika atau dimasa mendatang oleh pihak suami dengan mengucapkan kata-kata tertentu atau cara lain yang menggantikan kedudukan katakata tersebut. ${ }^{17}$

Jadi talak ialah, menghilangkan ikatan perkawinan sehingga setelah hilangnya ikatan perkawinan itu isteri tidak lagi halal bagi suaminya, dan ini terjadi dalam hal talak bain, sedangkan arti mengurangi pelepasan ikatan perkawinan ialah berkurangnya hak talak bagi suami yang mengakibatkan berkurangnya jumlah talak yang menjadi hak suami dari tiga menjadi dua, dari dua menjadi satu, dan dari satu menjadi hilang hak talak itu, yaitu terjadi dalam talak raj'i. ${ }^{18}$

Talak disyariatkan dalam al-Qur'an, sunah dan juga ijmak. Meskipun sebenarnya talak itu dibenci Allah, hal ini masih dibolehkan selama pernikahan yang terjadi tidak dapat dipertahankan lagi. Ini merupakan cara yang terakhir ditempuh dalam suatu pernikahan jika pernikahan tersebut menjumpai masalah yang tidak dapat diselesaikan melalui jalan perdamaian. ${ }^{19}$ Landasan hukum talak di dalam al Qur'an dijelaskan dalam surat Al-Baqarah: 232:

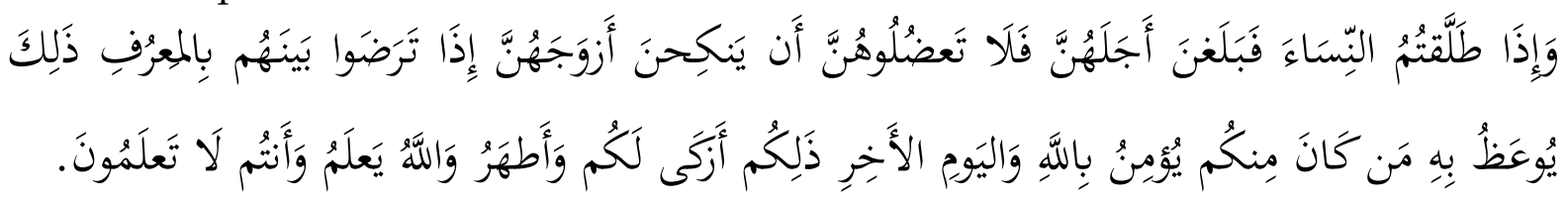

Artinya:

“Apabila kamu mentalak isteri-isterimu, lalu habis masa iddahnya, maka janganlah kamu (para wali) menghalangi mereka kawin lagi dengan bakal suaminya, apabila telah terdapat kerelaan diantara mereka dengan cara yang ma'ruf. Itulah yang dinasehatkan kepada orang-orang yang beriman diantara kamu kepada Allah dan hari kemudian. Itu lebih baik bagimu dan lebih suci. Allah mengetahui, sedangkan kamu tidak mengetahui". (QS. Al-Baqarah: 232) ${ }^{20}$.

Para ulama fikih berbeda pendapat tentang hukum talak, tapi pendapat yang paling kuat adalah pendapat yang mengatakan bahwa talak dilarang oleh agama, kecuali dalam keadaan mendesak. Pendapat ini bersumber dari ulama Hanafiah dan Hanabilah yang pendapat itu berlandaskan pada sabda Rasulullah SAW:

${ }^{16}$ Nurmala Fahriyanti, “GUGAT CERAI: MEMBEBASKAN PREMPUAN DARI

PENDERITAAN," QAWWAM 13, no. 2 (December 30, 2019): 101-22,

https://doi.org/10.20414/qawwam.v13i2.1468.

${ }^{17}$ Ibrahim Muhammad. Al-Jammal and H M Yusuf. Sinaga, Fiqh wanita (Johor Bahru:

Perniagaan Jahabersa, 2012).

${ }_{18}$ Ahmad Saebani, FIQH MUNAKAHAT 2.

${ }^{19}$ Suhaila Zulkifli, “PUTUSNYA PERKAWINAN AKIBAT SUAMI MENIKAH TANPA IZIN

DARI ISTRI," Jurnal Hukum Kaidah: Media Komunikasi Dan Informasi Hukum Dan Masyarakat 18, no. 3 (April 15, 2019): 14-26, https://doi.org/10.30743/jhk.v18i3.1184.

${ }^{20}$ Indonesia. and Lajnah Pentashihan Mushaf al-Qur'an, Al-Qur'an dan terjemahannya., 2019. 


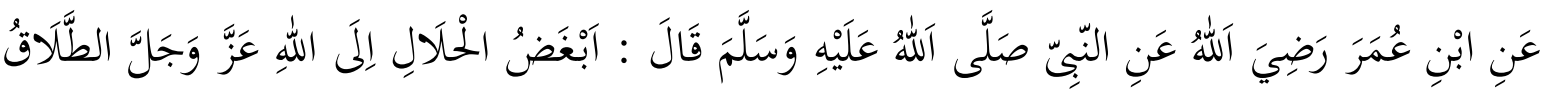

Artinya:

“Dari Ibnu Umar ra. dari Nabi saw, bersabda “Perkara halal yang paling dibenci Allah "Azza Wa Jalla ialah talak".21

Rukun talak unsur pokok yang harus ada dalam talak dan terwujudnya talak bergantung ada dan lengkapnya unsur-unsur dimaksud. Rukun talak ada empat, yaitu:22

a. Suami

Suami adalah yang memiliki hak talak dan yang berhak menjatuhkannya, selain suami tidak berhak menjatuhkannya. Oleh karena talak itu bersifat menghilangkan ikatan perkawinan maka talak tidak mungkin terwujud kecuali setelah nyata adanya akad perkawinan yang sah. Abu Ya'la dan Al-Hakim meriwayatkan hadis dari Jabir bahwa Rasulullah bersabda:

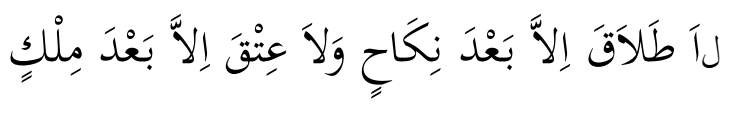

"Tidak ada talak kecuali setelah akad perkawinan dan tidak ada pemerdekaan kecuali setelah ada pemilikan".

Abu Daud dan Al-Tirmizi meriwayatkan hadis dari Amir ibn Syu'aib bahwa Rasulullah bersabda:

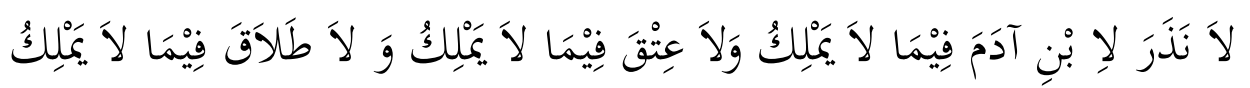

“Tidak ada nazar bagi anak Adam (manusia) tentang hal yang baik dimiliki, tidak ada pemerdekaan budak dalam hal yang tidak dimiliki, dan tidak ada talak dalam hal yang tidak dimiliki".

Untuk sahnya talak, suami yang menjatuhkan talak disyaratkan:23

1) Berakal. Suami yang gila tidak sah menjatuhkan talak. Yang dimaksud dengan gila dalam hal ini ialah hilang akal atau rusak akal karena sakit, termasuk kedalamnya sakit pitam, hilang akal karena sakit panas, atau sakit ingatan karena rusak syaraf otaknya.

2) Balig. Tidak dipandang jatuh talak yang dinyatakan oleh orang yang belum dewasa. Dalam hal ini ulama Hanabilah mengatakan bahwa talak oleh anak yang sudah mumayiz kendati umur anak itu kurang dari 10 tahun asalkan ia telah mengenal arti talak dan mengetahui akibatnya, talaknya dipandang jatuh.

3) Atas kemauan sendiri. Yang dimaksud atas kemauan sendiri di sini ialah adanya kehendak pada diri suami untuk menjatuhkan talak itu dan dijatuhkan atas pilihan sendiri, bukan dipaksa orang lain. Kehendak dan kesukarelaan melakukan perbuatan menjadi dasar taklif dan pertanggungjawaban. Oleh karena itu, orang yang dipaksa melakukan

\footnotetext{
${ }^{21}$ Al-Jammal and Sinaga, Figh wanita.

22 Al-Jammal and Sinaga.

${ }^{23}$ Al-Jammal and Sinaga.
} 
sesuatu (dalam hal ini menjatuhkan talak) tidak bertanggungjawab atas perbuatannya. Hal ini sesuai dengan sabda Rasulullah SAW: ${ }^{24}$

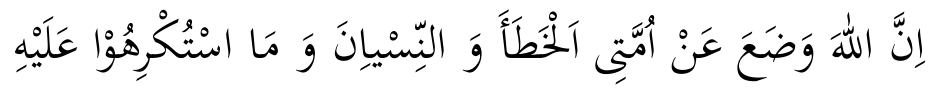

"Sungguh Allah melepaskan dari umatku tanggung jawab dari dosa silap, lupa dan sesuatu yang dipaksakan kepadanya".

b. Isteri

Masing-masing suami hanya berhak menjatuhkan talak terhadap isterinya sendiri. Tidak dipandang jatuh talak yang dijatuhkan terhadap isteri orang lain. Untuk sahnya talak, bagi isteri yang ditalak disyaratkan sebagai berikut:25

1) Isteri itu masih tetap berada dalam perlindungan kekuasaan suami. Isteri yang menjalin masa idah talak raj'i dari suaminya oleh hukum Islam dipandang masih berada dalam perlindungan kekuasaan suami. Karenanya ia dalam masa itu suami menjatuhkan talak lagi, dipandang jatuh talaknya sehingga menambah jumlah talak yang dijatuhkan dan mengurangi hak talak yang dimiliki suami. Dalam hal talak bain, bekas suami tidak berhak menjatuhkan talak lagi terhadap bekas isterinya meski dalam masa idahnya, karena dengan talak bain itu bekas isteri tidak lagi berada dalam perlindungan kekuasaan bekas suami.

2) Kedudukan isteri yang ditalak itu harus berdasarkan atas akad perkawinan yang sah. Jika ia menjadi isteri dengan akad nikah yang batil, seperti akad nikah terhadap wanita dalam masa idahnya, atau akad nikah dengan perempuan saudara isterinya (memadu antara dua perempuan bersaudara), atau akad nikah dengan anak tirinya padahal suami pernah menggauli ibu anak tirinya itu dan anak tiri itu berada dalam pemeliharaannya, maka talak yang demikian tidak dipandang ada. ${ }^{26}$

c. Sighhah Talak

Sighah talak ialah kata-kata yang diucapkan oleh suami terhadap isterinya yang menunjukkan talak, baik itu șarih (jelas) maupun kinayah (sindiran), baik berupa ucapan, lisan, tulisan, isyarat bagi suami tuna wicara atau pun dengan suruhan orang lain. Talak tidak dipandang jatuh jika perbuatan suami terhadap isterinya menunjukkan kemarahannya, semisal suami memarahi isteri, memukulnya, mengantarkannya ke rumah orang tuanya, menyerahkan barangbarangnya, tanpa disertai pernyataan talak, maka yang demikian itu bukan talak. Demikian pula niat talak atau masih berada dalam pikiran dan angan-angan, tidak diucapkan, tidak dipandang sebagai talak. Pembicaraan suami tentang talak tetapi tidak ditujukan terhadap isterinya juga tidak dipandang sebagai talak.

d. Qașdu (Sengaja)

Artinya bahwa dengan ucapan talak itu memang dimaksudkan oleh yang mengucapkannya untuk talak, bukan untuk maksud lain. Oleh karena itu, salah

\footnotetext{
24 Al-Jammal and Sinaga.

25 Al-Jammal and Sinaga.

26 Al-Jammal and Sinaga.
} 
ucap yang tidak dimaksud untuk talak dipandang tidak jatuh talak, seperti suami memberikan sebuah salak pada isterinya, semestinya ia mengatakan kepada isterinya itu kata-kata: "Ini sebuah salak untukmu", tetapi keliru ucapan, berbunyi: "Ini sebuah talak untukmu", maka talak tidak dipandang jatuh. ${ }^{27}$

Putusnya perkawinan adalah istilah hukum yang digunakan dalam UndangUndang Perkawinan untuk menjelaskan perceraian atau berakhirnya hubungan perkawinan antara seorang laki-laki dengan perempuan yang telah hidup sebagai seorang suami isteri.28 Dalam Undang-Undang Nomor 1 Tahun 1974 tentang perkawinan dijelaskan bahwa perceraian hanya dapat dilakukan di depan pengadilan setelah pengadilan yang bersangkutan berusaha dan tidak berhasil mendamaikan kedua belah pihak. ${ }^{29}$ Hal ini juga dijelaskan dalam Undang-Undang Perkawinan Nomor 1 Tahun 1974 Pasal 39:

a. Perceraian hanya dapat dilakukan di depan sidang pengadilan setelah pengadilan yang bersangkutan berusaha dan tidak berhasil mendamaikan kedua belah pihak.

b. Untuk melakukan perceraian harus ada cukup alasan bahwa antara suami isteri itu tidak akan dapat rukun sebagai suami isteri.

c. Tata cara perceraian di depan sidang pengadilan diatur dalam Peraturan Perundangan tersebut. ${ }^{30}$

Sebagaimana yang disebut dalam Pasal 1 Undang-Undang Nomor 1 Tahun 1974 dijelaskan bahwa tujuan perkawinan adalah membentuk keluarga bahagia, kekal, berdasarkan Ketuhanan Yang Maha Esa atau dalam KHI disebut dengan Mithaqan ghaliza (ikatan yang kuat), namun dalam realitanya sering kali perkawinan tersebut kandas ditengah jalan yang mengakibatkan putusnya perkawinan baik karena sebab kematian, perceraian ataupun karena putusan pengadilan berdasarkan syarat-syarat yang telah ditetapkan oleh Undang-Undang. ${ }^{31}$

Pasal yang menyebutkan bahwasanya perkawinan dapat putus ada beberapa sebab, yakni dalam Pasal 38 Undang-Undang Perkawinan dinyatakan bahwasanya perkawinan dapat putus karena kematian, perceraian, dan atas keputusan pengadilan. ${ }^{32}$ Kematian sebagai penyebab putusnya perkawinan adalah jika salah satu pihak baik suami atau isteri meninggal dunia. Sedangkan untuk sebab perceraian, Undang-Undang Perkawinan memberikan aturan-aturan yang telah baku, terperinci, dan sangat jelas. Adapun putusnya perkawinan dengan keputusan pengadilan adalah jika kepergian salah satu pihak tanpa kabar untuk waktu yang lama. Undang-Undang Perkawinan tidak menyebutnya berapa lama jangka waktu untuk menetapkan hilangnya atau dianggap meninggalnya seseorang itu. ${ }^{33}$ Di dalam PP Nomor 9 Tahun 1975 Pasal 19

${ }^{27}$ Al-Jammal and Sinaga.

${ }^{28}$ Indonesia., Undang-undang perkawinan : Undang-undang Republik Indonesia nomor 1 tahun 1974 tentang perkawinan : berikut penjelasannya.

${ }^{29}$ Indonesia.

${ }^{30}$ Indonesia.

${ }^{31}$ Martiman Prodjohamidjojo, Hukum Perkawinan Indonesia (Indonesia legal Center Publishing, 2012).

32 Indonesia. and Direktorat Pembinaan Badan Peradilan Agama Islam., Himpunan peraturan perundang-undangan dalam lingkungan peradilan agama. ([Jakarta]: Direktorat Pembinaan Badan Peradilan Agama Islam, Direktorat Jenderal Pembinaan Kelembagaan Agama Islam, Departemen Agama RI, 2001).

${ }^{33}$ HENDRI K, "PROBLEMATIKA HUKUM PERKAWINAN (Analisis Terhadap Ketentaun Pencatatan Perkawinan Dalam Perudang-Undangan Islam Indonesia Dan Malaysia)," Hukum Islam; 
dinyatakan bahwa hal-hal yang menyebabkan perceraian dapat terjadi karena alasanalasan:

a. Perceraian dapat terjadi karena salah satu pihak berbuat zina atau menjadi pemabuk, pemadat, penjudi dan lain sebagainya yang tidak dapat disembuhkan.

b. Salah satu pihak meninggalkan pihak lain selama 2 tahun berturut-turut tanpa izin pihak yang lain dan tanpa alasan yang sah atau karena hal lain di luar kemampuannya.

c. Salah satu pihak mendapatkan hukuman penjara 5 tahun atau hukuman yang berat setelah perkawinan berlangsung.

d. Salah satu pihak melakukan kekejaman atau penganiayaan berat yang membahayakan pihak yang lain.

e. Salah satu pihak mendapat cacat badan atau penyakit dengan akibat tidak dapat menjalankan kewajiban sebagai suami isteri.

f. Antara suami isteri terus menerus terjadi perselisihan dan pertengkaran dan tidak ada harapan akan hidup rukun lagi dalam rumah tangga. ${ }^{34}$

Dalam perundang-undangan Indonesia mengenai perceraian ini diatur dalam Undang-Undang Nomor 1 Tahun 1974 tentang Perkawinan yang tercantum dalam Pasal 38-41. Pada Pasal 38 Undang-Undang Nomor 1 Tahun 1974 tentang Perkawinan disebutkan bahwa perkawinan dapat putus karena: (1) Kematian, (2) Perceraian, (3) Atas Putusan Pengadilan.

Dalam perundang-undangan Indonesia, dibedakan antara perceraian atas kehendak suami dan perceraian atas kehendak isteri. Hal ini karena karakteristik hukum Islam dalam perceraian memang menghendaki demikian sehingga proses penyelesaiannya berbeda. ${ }^{35}$

Kematian sebagai salah satu sebab putusnya perkawinan adalah jika salah satu pihak baik suami atau isteri meninggal dunia. Sedangkan untuk sebab perceraian, Undang-Undang memberikan aturan-aturan yang telah baku, terperinci, dan sangat jelas. Adapun putusnya perkawinan dengan keputusan Pengadilan adalah jika kepergian salah satu pihak tanpa kabar untuk waktu yang lama. Undang-Undang Perkawinan tidak menyebutkan berapa lama jangka waktu untuk menetapkan hilangnya atau dianggap meninggalnya seseorang itu.

Undang-Undang membedakan antara perceraian atas kehendak suami dan perceraian atas kehendak isteri. Hal ini karena karakteristik hukum Islam dalam perceraian memang menghendaki demikian. Sehingga proses atas kehendak suami berbeda dengan proses perceraian atas kehendak isteri. ${ }^{36}$

Perceraian atas kehendak suami disebut dengan cerai talak dan perceraian atas kehendak isteri disebut dengan cerai gugat.

a. Cerai Talak

Vol 20, No 1 (2020): PROBLEMATIKA HUKUM KELUARGA DAN EKONOMI SYARI'AHDO 10.24014/Jhi.V20i1.8180, July 27, 2020, http:/ / ejournal.uin-

suska.ac.id/index.php/hukumislam/article/view/8180.

${ }^{34} \mathrm{~K}$.

${ }^{35}$ A Mukti Arto, Praktek perkara perdata pada pengadilan agama (Yogyakarta: Pustaka Pelajar, 1996).

36 Arto. 
Cerai talak yaitu apabila suami mengajukan gugatan ke Pengadilan untuk menceraiakan isterinya, kemudian sang isteri menyetujuinya. Mengenai hal pengajuan gugatan cerai talak ke Pengadilan. PP Nomer 9 Tahun 1975 mengaturnya dalam Pasal 14: "Seorang suami yang telah melangsungkan perkawinan menurut agama Islam, yang akan menceraikan isterinya, mengajukan surat kepada Pengadilan di tempat tinggalnya, yang berisi pemberitahuan bahwa ia bermaksud menceraikan isterinya disertai dengan alasan-alasan serta meminta kepada Pengadilan agar diadakan sidang untuk keperluan itu"

b. Cerai Gugat

Cerai gugat yaitu ikatan perkawinan yang putus sebagai akibat gugatan yang diajukan oleh isteri ke Pengadilan Agama yang kemudian termohon (suami) menyetujui, sehingga Pengadilan Agama mengabulkan gugatan yang dimaksud. Oleh karena itu, khuluk termasuk cerai gugat. Khuluk adalah perceraian yang terjadi atas permintaan isteri dengan memberikan tebusan atau uang iwad kepada dan atas persetujuan suaminya. ${ }^{37}$

Dalam Kompilasi Hukum Islam (KHI) bahwa akibat dari perceraian dijelaskan dalam Pasal 149 sampai dengan Pasal 160, yaitu: Pasal 149 menjelaskan kewajiban suami setelah perceraian harus memberikan mutah kepada bekas isterinya dengan jumlah atau kadar yang wajar kecuali bila isterinya qabl al-dukhu<l; memberi nafkah kepada bekas isteri selama berlangsungnya masa idah kecuali jika isteri tersebut dijatuhi talak bain atau nusyuz dan dalam keadaan hamil; membayar lunas mahar yang belum dibayarkan dan memberikan hak khazanah kepada anaknya yang belum berumur 21 tahun. ${ }^{38}$

Pasal 150 sampai Pasal 151 berisi bolehnya bagi suami untuk merujuk isterinya yang masih dalam masa idah dan untuk isteri yang masih dalam masa idah mempunyai kewajiban untuk menjaga dirinya dan tidak menerima pinangan dari orang lain. Sedangkan dalam Pasal 151 dijelaskan bagi isteri berhak menerima nafkah idah jika dia tidak nusyuz. ${ }^{39}$

Selanjutnya dalam Pasal 153 yang berisi sebanyak enam ayat di dalamnya menjelaskan resiko bagi wanita yang bercerai dari suaminya untuk melaksanakan idah yang hitungannya bermacam-macam tergantung dari kondisi dimana suami isteri tersebut berpisah. Dalam Pasal itu juga terdapat pengeculian bahwa tidak ada masa idah bagi bekas isteri jika bercerai qabl al-dukhul. ${ }^{40}$

Pasal 154 dan Pasal 155 belum beranjak dari masa tunggu (idah) untuk wanita yang bercerai karena khuluk, fasakh, dan lian berlaku juga idah talak. Sedangkan untuk isteri yang ditinggal mati suaminya idahnya menjadi empat bulan sepuluh hari yang dihitung sejak kematian suaminya. ${ }^{41}$

37 Amran Suadi, “PERKEMBANGAN HUKUM PERDATA ISLAM DI INDONESIA (Aspek Perkawinan Dan Kewarisan )," Jurnal Yuridis 2, no. 1 (2015): 1-27,

https://doi.org/http://dx.doi.org/10.35586/.v2i1.155.

38 Suadi.

${ }^{39}$ Suadi.

40 Suadi.

${ }^{41}$ Euis. Nurlaelawati, "Modernization Tradition and Identity : The Kompilasi Hukum Islam and Legal Practice in the Indonesian Religious Courts" (Amsterdam: Amsterdam University Press, 2010), http:// site.ebrary.com/id/10397469. 
Sedangkan untuk Pasal 156 menjelaskan akibat dari perceraian yang mengatur tentang hak pemeliharaan dan biaya keperluan anak dari mulai anak yang belum mumayiz sampai anak yang sudah mumayiz oleh pihak-pihak yang bersangkutan dengan perceraian yang terjadi. ${ }^{42}$

Kemudian Pasal 157 mengatur tentang harta bersama yang harus diperhitungkan ketika perceraian terjadi. Sedang Pasal 158 sampai dengan 160 membicarakan mengenai mutah yang wajib dibayarkan oleh bekas suami kepada bekas isteri dengan syaratsyarat tertentu yang diatur dalam Kompilasi Hukum Islam dan Sunah diberikan oleh bekas suami tanpa syarat serta besarnya mutah itu sendiri. ${ }^{43}$

\section{KASUS TALAK DI LUAR PENGADILAN}

Melakukan perceraian di luar Pengadilan memang bukanlah sebuah kejahatan. Sebab hingga saat ini tidak ada satu aturan pun yang menyatakan bahwa perbuatan tersebut dapat dihukum. Akibatnya sering terjadi kesewenang-wenangan dari satu pihak yang pada akhirnya bisa merugikan pihak lainnya, bahkan bisa juga merugikan keduanya.

Peneliti berhasil mewawancarai lima responden warga kecamatan Pacitan yang telah bercerai di luar pengadilan. 4 dari delapan responden bekerja sebagai ibu rumah tangga sedangkan sisanya adalah guru. Dari hasil wawancara diketahui bahwa praktik perceraian di luar pengadilan oleh masyarakat kecamatan Pacitan dilakukan dengan menggunakan dua model, yaitu:

Melalui perantara, berdasarkan wawancara yang dilakukan dengan delapan responden yang bercerai di luar pengadilan, satu responden melakukan perceraian di luar pengadilan melalui pihak perantara. Proses perceraian melalui perantara ini dilakukan dengan cara, kedua belah pihak mendatangi perantara, kemudian perantara menjelaskan bahwa perceraian harus dilakukan melalui prosedur pengadilan agar perceraian itu sah di mata negara. Usai menjelaskan hal tersebut, perantara kemudian menanyakan apakah keduanya ingin bercerai tanpa melalui proses pengadilan. Setelah keduanya sepakat untuk bercerai tanpa melalui proses pengadilan atau dengan kata lain di luar pengadilan, maka kedua belah pihak diminta untuk membuat pernyataan talak/cerai.

Dalam mekanisme yang pertama ini suami-istri membuat surat pernyataan. Dalam pernyataan tersebut menyatakan, "Ini adalah pernyataan talak/cerai yang saya buat, dan saya menandatanganinya dengan baik dalam keadaan sehat jasmani dan rohani dan disaksikan oleh beberapa saksi yang juga menandatangani pernyataan ini. Adapun perceraian ini atas kehendak keduanya. dari kami tanpa paksaan dari pihak lain. Jika di kemudian hari istri saya mendapat jodoh yang berbeda, maka talak/pernyataan cerai ini merupakan bukti perceraian kami, sehingga dapat dipergunakan sebagaimana mestinya."

Berdasarkan wawancara yang dilakukan kepada lima responden yang bercerai di luar pengadilan, empat responden melakukan proses perceraian di luar pengadilan dengan didampingi keluarga saja. Seorang responden mengatakan bahwa perceraiannya hanya disaksikan oleh keluarganya, dimana suaminya menjatuhkan talak di depan keluarganya dan menyerahkannya kembali kepada keluarganya. Setelah menjatuhkan talak di depan keluarganya, suaminya meninggalkan si istri, dan sampai sekarang tidak ada kabar dari suaminya. Tidak jauh berbeda dengan responden

42 Nurlaelawati.

43 Nurlaelawati. 
lainnya, perceraian responden kedua dengan suaminya juga hanya dilakukan kekerabatan dimana suaminya menjatuhkan talak di depan keluarganya. Awalnya, dia meminta suaminya membuat akta cerai yang ditandatangani kedua belah pihak dan RT serta ketua Amil sebagai saksi. Namun, suaminya menolak hingga akhirnya perceraian hanya dilakukan secara kekeluargaan.

Berdasarkan hasil wawancara yang telah dilakukan peneliti dengan responden, telah diperoleh beberapa data terkait talak di luar Pengadilan. Salah satu responden mengungkapkan penyebab terjadinya percekcokan dengan istrinya yang didasari oleh tuntutan istri untuk meminta nafkah lebih. Selain itu peneliti juga memperoleh data terkait kondisi rumah tangga pasangan suami istri setelah terjadinya percekcokan, dimana rumah tangga mereka sering mengalami percekcokan. Seperti yang disampaikan oleh oleh salah satu narasumber, bahwa awalnya istrinya masih bisa dinasehati oleh keluarga, namun selang beberapa bulan mereka bertengkar lagi dengan persoalan yang sama karena suami masih belum bisa memenuhi tuntutannya. Bahkan hampir setiap hari mereka selalu bertengkar dan sudah tidak berhubungan layaknya suami istri lagi. Pada akhirnya istri memilih untuk meninggalkan rumah kemudian tinggal di rumah saudaranya.

Terkait sudah adanya usaha untuk berdamai dengan istrinya, sebenarnya dari pihak keluarga sudah ada usaha untuk mendamaikan dan menasehati istri untuk bisa menerima nafkah yang diberikan oleh suami namun istri tetap bersikukuh menuntut nafkah lebih. Berhubung istri tidak bisa untuk diajak damai suami memilih mengajukan gugatan ke Pengadilan karena suami merasa tidak kuat dengan sikap istrinya yang terus menerus menuntut nafkah di luar batas kemampuan suami, dan suami merasa sudah tidak bisa mempertahankan rumah tangga ini". Dari penuturan responden tersebut diketahui bahwa sebenarnya sudah ada usaha untuk mendamaikan responden dengan istrinya, namun sikap dari istri responden yang tidak bisa menerima penghasilan dari responden dan sikap menuntut nafkah yang lebih secara terusmenurus yang menjadi alasan dari responden untuk mengajukan gugatan cerai ke pengadilan.

Dengan adanya percekcokan yang hampir setiap hari terjadi, mengakibatkan suami menjatuhkan talak terhadap istrinya ketika bertengkar di rumah. Hal tersebut peneliti ketahui pada saat menanyakan kepada narasumber, bahwa suami pernah mengucapkan talak lebih dari tiga kali dalam satu waktu, hal itu terjadi karena suami merasa muak karena selalu dituntut untuk memberinya nafkah lebih sedangkan suami hanya bisa memberinya nafkah sesuai kemampuannya yang hanya berprofesi sebagai sopir. Selain itu suami juga merasa sudah tidak bisa mempertahankan rumah tangganya". ${ }^{4}$

Berdasarkan jawaban responden terhadap pertanyaan peneliti tersebut di atas, diketahui bahwa responden telah menjatuhkan talak terhadap istrinya ketika bertengkar di rumah. Dimana talak yang telah dijatuhkan responden terhadap istrinya telak diucapkan berulang kali. Hal tersebut didasari atas sikap responden yang sudah tidak tahan dan kesal terhadap sikap istrinya yang tidak bisa menerima keadaan responden yang mana tidak dapat memberikan nafkah sesuai dengan tuntutan istrinya.

Peneliti menanyakan kepada suami terkait praktek talak yang telah diucapkan pada saat di rumah terhadap istrinya, bahwa pada saat bertengkar dengan istrinya suami pernah mengucapkan "sudah kita bercerai saja dari pada kamu selalu menuntut yang sudah pasti saya tidak bisa menuruti" dan itu terjadi setiap saya bertengkar dengan istri selalu diucapkan."

${ }^{44}$ Abdul (Nama Samaran), "Hasil Wawancara." 
Berdasarkan jawaban responden di atas telah diketahui bahwa ucapan tersebut termasuk ke dalam kategori talak dengan ucapan dan termasuk dalam ucapan Sari<h karena kata-kata yang digunakan jelas, tegas dan dapat dipahami sebagai pernyataan talak.

Terkait surat gugatan di persidangan, responden menyampaikan bahwa telah mengajukan surat gugatan di pengadilan yang dibuat oleh kuasa hukumnya". Berdasarkan hasil wawancara yang telah dilakukan peneliti dengan responden, telah diketahui bahwa segala hal yang bersangkutan dengan administrasi selama proses persidangan telah diwakilkan oleh kuasa hukum dengan surat kuasa khusus, yang mana pihak responden hanya menyampaikan kepada kuasa hukum bahwa dirinya ingin bercerai dengan istri dan menginginkan hak asuh anak tetap jatuh dibawah asuhan responden. Beliau menambahkan bahwa selama persidangan majelis hakim tidak menanyakan talak yang telah dijatuhkan beliau ketika di rumah.

Selain melakukan wawancara dengan pihak suami peneliti juga melakukan wawancara dengan pihak istri untuk mendapatkan data yang valid tentang talak yang dilakukan di rumah. Peneliti menanyakan terkait faktor penyebab terjadinya percekcokan yang mengakibatkan perceraian. Pihak istri menjelaskan bahwa perceraian tersebut terjadi karena adanya masalah ekonomi. Nafkah yang diberikan oleh mantan suami menurutnya tidak cukup untuk memenuhi kebutuhan sehari-hari, karena kebutuhan yang semakin hari semakin banyak. Dan setiap kali istri meminta agar diberikan nafkah yang lebih dari biasanya mantan suami justru marah kepadanya". Selanjutnya peneliti menanyakan terkait kondisi rumah tangga setelah terjadinya percekcokan, pihak istri menegaskan bahwa pada mulanya istri dulu pernah dinasehati oleh keluarga mantan suaminya, namun istri tetap meminta agar diberikan nafkah yang lebih, karena yang diberikan tidak cukup untuk memenuhi kebutuhan sehari-hari, sedangkan mantan suami dulu tidak mau tahu akan pengeluaran sehari-hari".

Selanjutnya peneliti menanyakan terkait ucapan talak yang telah diucapkan mantan suaminya, beliau mengatakan bahwa ucapan talak benar dilakukan, dan itu terjadi tidak hanya satu dua kali. Dulu pada saat bertengkar mantan suaminya pernah mengatakan bahwa akan menceraikan istri dengan alasan istri selalu menuntut nafkah yang lebih".

\section{ANALISIS MENGENAI STATUS TALAK DI LUAR PENGADILAN MENURUT HUKUM FIKIH DAN HUKUM POSITIF}

Menurut bahasa, al-țalaq, berasal dari kata al-ițlaq, yang berarti melepaskan atau meninggalkan. Dan menurut istilah syara' ialah melepaskan ikatan pernikahan dengan kata-kata atau lafal yang menunjukkan talak atau perceraian. Kata-kata talak atau cerai itu harus selalu dijaga ketat, tidak diucapkan dengan tergesa-gesa, penuh emosi dan tidak menggunakan hak mencerai ini sewenang-wenang.

Cerai atau talak untuk mengakhiri perkawinan merupakan suatu perbuatan yang diperbolehkan oleh Allah. Meski diperbolehkan, di sisi lain talak atau cerai merupakan suatu hal yang dibenci oleh Allah. Terkait dengan sisi legalitas dan kebencian Allah terhadap praktik cerai dapat terlihat dalam hadis berikut ini:

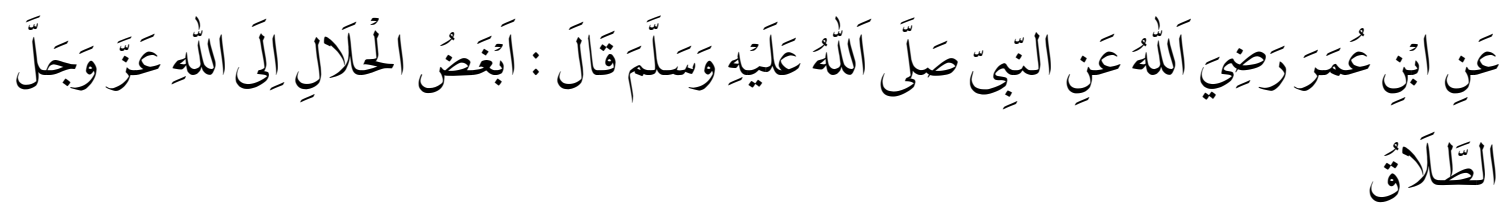

Artinya: 
"Dari Ibnu Umar ra. dari Nabi saw, bersabda "Perkara halal yang paling dibenci Allah "Azza Wa Jalla ialah talak".

Berdasarkan wawancara dengan Ketua Hakim Pengadilan Agama Pacitan, menurutnya talak di luar pengadilan adalah talak siri atau bisa juga disebut cerai tidak sah, yang jika dilihat dalam kitab-kitab fiqh klasik tergolong sah. Padahal menurut Undang-Undang Perkawinan dan Undang-Undang Nomor 7 Tahun 1989 tentang Peradilan Agama, perceraian adalah perbuatan melawan hukum. Meski beberapa kali sang suami mengucapkan kata talak. Jadi intinya perceraian di luar pengadilan tidak sah menurut hukum, dan di mata negara keduanya tetap suami istri. ${ }^{45}$

Berdasarkan hasil wawancara yang dilakukan peneliti dengan Bapak Abdul, Bapak Ghani, dan Bapak Ni'am telah diketahui bahwa ketiganya sudah menjatuhkan talak terhadap istrinya ketika di rumah. ${ }^{46}$ Bahkan salah satu pelaku pernah mengucapkan talak lebih dari tiga kali dalam satu waktu. Apabila dilihat berdasarkan hukum fikih, praktek talak di luar Pengadilan yang dilakukan oleh Bapak Abdul (nama samaran) sebagaimana paparan data di atas sah secara agama karena telah memenuhi syarat dan rukun talak. ${ }^{47}$

Adapun terkait dengan ucapan talak yang telah diucapkan pada saat cekcok dengan istri tiga responden mengucapkan talak berulang kali bahkan pernah mengucapkan talak dan salah satunya dilakukan lebih dari tiga kali dalam satu waktu, peneliti menyimpulkan bahwa status talak terutama yang diucapkan Bapak Abdul di rumah itu tetap sah menurut agama, karena telah memenuhi syarat dan rukun talak. Kesimpulan peneliti ini berdasar pada pendapat imam empat mazhab yang mengatakan ketika seorang suami mengucapkan talak tiga sekaligus dalam satu waktu termasuk jatuh talak tiga.

Menurut peneliti talak tersebut masuk ke dalam talak bain kubro. Karena talak bain kubro jatuh pada talak ketiga. Talak bain kubro yaitu talak yang menghilangkan pemilikan bekas suami terhadap bekas istri serta menghilangkan kehalalan bekas suami untuk kawin kembali dengan bekas istrinya, kecuali bekas istri itu kawin dengan lakilaki lain, telah berkumpul dengan suami kedua itu serta telah bercerai secara wajar dan telah selesai menjalankan idahnya. Akibat dari talak di luar pengadilan jika dilihat dari hukum fikih talak tersebut tetap sah, selain itu juga mengakibatkan hilangnya hubungan antara suami dan istri, hilangnya hak untuk menjatuhkan talak karena hak talak sudah dipergunakan seluruhnya, serta mantan istri harus menjalankan kewajiban idah terhitung sejak jatuhnya talak pada saat di rumah.

Dalam kasus Bapak Abdul sudah menjatuhkan talak ketika di rumah kepada istrinya, namun Bapak Abdul juga mengajukan gugatan talak di Pengadilan Agama untuk mendapatkan pengakuan dari negara bahwa telah bercerai dengan istrinya. Berdasarkan wawancara yang dilakukan peneliti terhadap Bapak Abdul serta salinan putusan yang diperoleh dari Pengadilan Agama Pacitan, diketahui bahwa di dalam surat gugatan tersebut berisikan meminta kepada Majelis Hakim untuk memberikan izin menjatuhkan talak satu raj'i. ${ }^{48}$

Selama proses persidangan berlangsung pihak Termohon sama sekali tidak memenuhi panggilan dari Pengadilan untuk menghadiri sidang, karena alasan tersebut Majelis Hakim mengabulkan gugatan Pemohon dengan tanpa hadirnya Termohon

\footnotetext{
45 Muhamad Rizki, “Hasil Wawancara” (Pacitan, 2020).

46 Abdul, Ni'am, and Ghani, "Hasil Wawancara" (Pacitan, 2020).

47 Abdul, Ni'am, and Ghani.

48 Abdul (Nama Samaran), "Hasil Wawancara."
} 
(verstek). Dikarenakan hal tersebut, upaya mediasi tidak dapat terlaksana, meskipun upaya mediasi tidak terlaksana Majelis Hakim tetap memberikan nasehat kepada responden untuk memikirkan kembali keputusan yang telah diambil agar tidak menyesal di kemudian hari. Di dalam salinan putusan diketahui Majelis Hakim memberikan izin kepada responden untuk menjatuhkan talak satu raj'i kepada istrinya, dimana hal tersebut sesuai dengan primer gugatan pemohon. Berdasarkan putusan tersebut hakim tidak salah memberikan izin untuk menjatuhkan talak satu raj'i karena baik di dalam Undang-Undang Perkawinan maupun Kompilasi Hukum Islam perceraian yang dianggap hanyalah perceraian yang dilakukan di persidangan Pengadilan Agama, dengan kata lain bahwa talak yang telak dijatuhkan oleh Bapak Abdul ketika di rumah tidak dianggap dan tidak sah menurut hukum positif yang berlaku di Indonesia.

Dari penjelasan di atas, peneliti menyimpulkan bahwa talak yang dijatuhkan Bapak Abdul ketika di rumah sah menurut hukum Fikih, akan tetapi talak tersebut tidak sah menurut hukum positif yang berlaku di Indonesia.

\section{ANALISIS MENGENAI DUA PROSES PERCERAIAN YANG DIJADIKAN PEDOMAN TERHADAP PUTUSNYA PERKAWINAN}

Berdasarkan paparan data di atas, dapat diketahui bahwa dua responden telah menjatuhkan talak kepada istrinya dan bahkan salah satu responden telah mengucapkan talak sebanyak tiga kali dalam satu waktu ketika bertengkar di rumah, dalam keadaan tersebut menurut hukum Islam dua responden masih memiliki hak talak, dan satu responden telah kehilangan hak talak yang dimiliki. Selain itu apabila bagi responden yang telah menjatuhkan talak dua kali bila ingin melakukan rujuk harus menunggu si istri menikah terlebih dahulu dengan orang lain karena talak yang telah dijatuhkan termasuk talak bain kubra. Percekcokan yang sering terjadi dengan istrinya mengakibatkan responden mengajukan gugatan ke Pengadilan Agama Pacitan. Tindakan yang dilakukan istri untuk mengajukan gugatan ke Pengadilan Agama sudah sesuai dengan tata cara perceraian yang mana hal tersebut telah diatur di dalam Undang-Undang Perkawinan.

Dalam Undang-Undang Nomor 1 Tahun 1974 Pasal 39 tentang perkawinan dijelaskan bahwa perceraian hanya dapat dilakukan di depan pengadilan setelah pengadilan yang bersangkutan berusaha dan tidak berhasil mendamaikan kedua belah pihak. Menurut peneliti, Pasal di atas secara tidak langsung menjelaskan bahwasanya tidak ada tempat lain yang digunakan untuk memproses perceraian selain Pengadilan Agama. ${ }^{49} \mathrm{Hal}$ tersebut ditegaskan dengan kata "hanya" yang menjelaskan bahwa tidak ada pilihan lain terkait dengan tempat pemrosesan perkara perceraian. Peneliti beranggapan bahwa Undang-Undang tersebut menjadi salah satu upaya pemerintah untuk memperkuat dan mempertegas aturan dari hukum Islam agar tidak terjadi kesewang-wenangan dalam penjatuhan talak. Dengan demikian, dapat dipastikan bahwasanya tempat pelaksanaan perceraian yang dilakukan oleh Bapak Abdul ketika di rumah tidak memenuhi syarat tempat sebagaimana dijelaskan dalam pasal tersebut.

Berdasarkan penjelasan di atas, dapat diketahui bahwasanya praktek perceraian yang dilakukan oleh beberapa responden di kecamatan Pacitan tidak sesuai dengan ketentuan Undang-Undang, yakni bahwa menurut Undang-Undang perceraian yang dianggap sah adalah perceraian yang dilaksanakan di depan Pengadilan Agama. Akibat

49 Indonesia., Undang-undang perkawinan : Undang-undang Republik Indonesia nomor 1 tahun 1974 tentang perkawinan : berikut penjelasannya. 
dari talak yang dilakukan di luar Pengadilan adalah ikatan perkawinan antara suami istri tersebut belum putus secara Undang-Undang, atau dengan kata lain baik suami istri tersebut masih tercatat sebagai suami istri.

Konsekuensi dari tindakan yang dilakukan oleh responden untuk mengajukan gugatan ke Pengadilan Agama adalah harus tetap menjalankan kewajibannya setelah dikeluarkannya putusan dari Pengadilan Agama semisal membayar biaya perkara yang dibebankan kepadanya. Peneliti setuju dengan tindakan yang telah dilakukan oleh salah satu responden yakni Bapak Abdul, karena apabila terjadi penyelewengan seperti tidak melaksanakan kewajibannya yang tercantum dalam isi putusan Pengadilan maka Bapak Abdul bisa dituntut secara hukum karena sudah ada putusan yang bersifat memaksa dan apabila tidak dipatuhi maka akan ada konsekuensinya tersendiri bagi Bapak Abdul.

Selain itu perceraian yang dilakukan di Pengadilan Agama bertujuan untuk memperoleh bukti konkrit atau bukti tertulis telah terjadinya talak. Dengan tidak adanya bukti, jika terjadi suatu masalah di kemudian hari, maka tidak akan ada yang menjadi penguat atau menjadi bukti untuk menyelesaikan masalah tersebut.

Setelah melalui proses persidangan didapatlah putusan, yang mana dalam putusan tersebut berisikan izin bagi Bapak Abdul untuk menjatuhkan talak satu Raj'i kepada istrinya yang mana hal tersebut sesuai dengan primer gugatan Pemohon. ${ }^{50}$ Berdasarkan putusan tersebut Bapak Abdul masih memiliki hak untuk rujuk (kembali) kepada istrinya tanpa adanya syarat istri nya menikah terlebih dahulu dengan orang lain. Hal ini berbeda dengan aturan hukum fikih yang mensyaratkan adanya pernikahan baru bagi istri Bapak Abdul dengan orang lain apabila Bapak Abdul ingin rujuk (kembali) dengan istrinya karena menurut hukum fikih talak yang dijatuhkan bapak Abdul di rumah termasuk talak bain kubro. ${ }^{51}$ Meskipun dalam putusan pengadilan berisikan izin untuk menjatuhkan talak satu raj'i yang mana hal tersebut masih memungkinkan adanya rujuk antara bapak Abdul dengan mantan istrinya, namun pada kenyataannya sampai saat ini bapak Abdul memilih untuk tidak rujuk dengan mantan istrinya dimana hal tersebut menurut peniliti telah mematuhi ketentuan talak yang ada dalam hukum Islam.

Dari penjelasan di atas, terlihat adanya dua proses perceraian yaitu perceraian yang terjadi di rumah yang sah menurut hukum fikih dan proses perceraian yang terjadi di Pengadilan Agama Pacitan yang sah secara hukum positif di Indonesia, yang mana dari dua proses perceraian tersebut memiliki akibat hukum yang berbeda. Dari penjelasan di atas, peneliti lebih memilih untuk menjadikan hukum positif yang berlaku di Indonesia sebagai pedoman terhadap putusnya perkawinan, dikarenakan akibat hukum yang ditimbulkan setelah terjadinya perceraian lebih diatur dengan jelas di dalam hukum positif, sehingga kewajiban dan hak yang timbul setelah terjadinya perceraian lebih terjamin. Sebagai contoh tentang adanya akibat hukum yang ditimbulkan setelah terjadinya perceraian menurut hukum positif yaitu tentang hak bagi istri untuk menerima nafkah idah jika dia tidak nusyuz.

\footnotetext{
50 Abdul (Nama Samaran), “Hasil Wawancara.”

${ }^{51}$ Huriyah (Nama Samaran), "Hasil Wawancara” (Pacitan, 2020).
} 


\section{CONCLUSION}

Dari beberapa pembahasan yang telah diuraikan pada bab-bab di atas, maka penulis menarik kesimpulan talak yang dijatuhkan di luar pengadilan adalah sah menurut hukum fikih, sehingga perkawinannya putus sesuai dengan aturan fikih. Namun perceraian tersebut tidak sah menurut hukum positif di Indonesia, sehingga di mata hukum positif perkawinannya belum putus. Hukum positif yang berlaku di Indonesia yang dijadikan sebagai pedoman terhadap putusnya perkawinan, dikarenakan akibat hukum yang ditimbulkan setelah terjadinya perceraian lebih diatur dengan jelas, sehingga kewajiban dan hak yang timbul setelah terjadinya perceraian lebih terjamin.

\section{REFERENCES}

Abdul (Nama Samaran). "Hasil Wawancara." Pacitan, 2020.

Abdul, Ni'am, and Ghani. "Hasil Wawancara." Pacitan, 2020.

Ahmad Saebani, Beni. FIQH MUNAKAHAT 2. Ed 1 cet 5. Bandung: Pustaka Setia, 2016.

Al-Jammal, Ibrahim Muhammad., and H M Yusuf. Sinaga. Fiqh wanita. Johor Bahru: Perniagaan Jahabersa, 2012.

Arto, A Mukti. Praktek perkara perdata pada pengadilan agama. Yogyakarta: Pustaka Pelajar, 1996.

Fahriyanti, Nurmala. “GUGAT CERAI: MEMBEBASKAN PREMPUAN DARI PENDERITAAN." QAWWAM 13, no. 2 (December 30, 2019): 101-22. https:/ / doi.org/10.20414/ qawwam.v13i2.1468.

Halil Nasution, Rusli. "TALAK MENURUT HUKUM ISLAM." Jumal Ilmiah Al-Hadi 3, no. 2 (2018): 707-16.

http://jurnal.pancabudi.ac.id/index.php/alhadi/article/view/357.

Huriyah (Nama Samaran). "Hasil Wawancara." Pacitan, 2020.

Indonesia. Undang-undang perkawinan : Undang-undang Republik Indonesia nomor 1 tahun 1974 tentang perkawinan : berikut penjelasannya. Jakarta: Alda/Pentja, 1974.

Indonesia., and Direktorat Pembinaan Badan Peradilan Agama Islam. Himpunan peraturan perundang-undangan dalam lingkungan peradilan agama. [Jakarta]: Direktorat Pembinaan Badan Peradilan Agama Islam, Direktorat Jenderal Pembinaan Kelembagaan Agama Islam, Departemen Agama RI, 2001.

Indonesia., and Lajnah Pentashihan Mushaf al-Qur'an. Al-Qur'an dan terjemahannya., 2019.

Isa, Muhammad. "PERCERAIAN DI LUAR PENGADILAN AGAMA MENURUT PERSPEKTIF UNDANG-UNDANG NOMOR 1 TAHUN 1974 DAN

KOMPILASI HUKUM ISLAM (Suatu Penelitian Di Wilayah Hukum Mahkamah Syar'iyah Aceh Besar)." Jurnal Ilmu Hukum 2, no. 1 (2014).

K, HENDRI. "PROBLEMATIKA HUKUM PERKAWINAN (Analisis Terhadap

Ketentaun Pencatatan Perkawinan Dalam Perudang-Undangan Islam Indonesia Dan Malaysia)." Hukum Islam; Vol 20, No 1 (2020): PROBLEMATIKA HUKUM KELUARGA DAN EKONOMI SYARIE\#039;AHDO - 10.24014/Jhi.V20i1.8180 , July 27, 2020. http:/ / ejournal.uinsuska.ac.id/index.php/hukumislam/article/view/8180.

Majid, Sofi' ul, Yasin Arief, and Nur'i Yakin. "PRAKTIK PERCERAIAN DI LUAR 
PENGADILAN AGAMA DALAM PERSPEKTIF KOMPILASI HUKUM ISLAM (Studi Kasus Desa Sirahan Kec. Cluwak Kab. Pati (2017)." In KONFERENSI ILMIAH MAHASISWA UNISSULA (KIMU) 2, 1256-62, 2019.

Mas'ud, Ibnu, and Zainal Abidin. Fiqih madzhab Syafi'i. Bandung: Pustaka Setia, 2000. Nurlaelawati, Euis. "Modernization Tradition and Identity: The Kompilasi Hukum Islam and Legal Practice in the Indonesian Religious Courts." Amsterdam: Amsterdam University Press, 2010. http:// site.ebrary.com/id/10397469.

Prodjohamidjojo, Martiman. Hukum Perkawinan Indonesia. Indonesia legal Center Publishing, 2012.

Rizki, Muhamad. “Hasil Wawancara.” Pacitan, 2020.

Rohmad (Nama Samaran). "Hasil Wawancara Dengan Hakim PA Dan Masyarakat Sekitar." Pacitan, 2020.

Sabiq, As-Sayyid., Nor Hasanuddin., Aisyah Saipuddin., and Johari al- Yamani. Figh Sunnah. Kuala Lumpur: Al-Hidayah Publication, 2009.

Suadi, Amran. "PERKEMBANGAN HUKUM PERDATA ISLAM DI INDONESIA (Aspek Perkawinan Dan Kewarisan )." Jurnal Yuridis 2, no. 1 (2015): 1-27. https:/ / doi.org/http:/ / dx.doi.org/10.35586/.v2i1.155.

Zainuddin, Zainuddin, Khairina Khairina, and Sulastri Caniago. "ITSBAT TALAK DALAM PERSPEKTIF HUKUM PERKAWINAN DI INDONESIA." Al-Ahwal: Jurnal Hukum Keluarga Islam 12, no. 1 (August 7, 2020): 29. https:/ / doi.org/10.14421/ahwal.2019.12103.

Zulkifli, Suhaila. "PUTUSNYA PERKAWINAN AKIBAT SUAMI MENIKAH TANPA IZIN DARI ISTRI." Jurnal Hukum Kaidah: Media Komunikasi Dan Informasi Hukum Dan Masyarakat 18, no. 3 (April 15, 2019): 14-26. https://doi.org/10.30743/jhk.v18i3.1184. 